\title{
Effect of Face-to-Face Tutoring on Academic Performance of Distance Learners: Implications for Educational Practice
}

\author{
Vera Arhin, Samuel Yaw Ampofo*, Moses Segbenya, Beatrice Asante Somauh, \\ Vincent Mensah Minadzi, Lydia Aframea Dankyi, Paul Mensah Agyei, \\ Joyce Kwakyewaa Dankyi, John Ekow Laryea, Peter Brown
}

College of Distance Education, University of Cape Coast, Cape Coast, Ghana

Received November 22, 2020; Revised February 18, 2021; Accepted March 12, 2021

\section{Cite This Paper in the following Citation Styles}

(a): [1] Vera Arhin, Samuel Yaw Ampofo, Moses Segbenya, Beatrice Asante Somauh, Vincent Mensah Minadzi, Lydia Aframea Dankyi, Paul Mensah Agyei, Joyce Kwakyewaa Dankyi, John Ekow Laryea, Peter Brown, "Effect of Face-to-Face Tutoring on Academic Performance of Distance Learners: Implications for Educational Practice," Universal Journal of Educational Research, Vol. 9, No. 3, pp. 593 - 605, 2021. DOI: 10.13189/ujer.2021.090319.

(b): Vera Arhin, Samuel Yaw Ampofo, Moses Segbenya, Beatrice Asante Somauh, Vincent Mensah Minadzi, Lydia Aframea Dankyi, Paul Mensah Agyei, Joyce Kwakyewaa Dankyi, John Ekow Laryea, Peter Brown (2021). Effect of Face-to-Face Tutoring on Academic Performance of Distance Learners: Implications for Educational Practice. Universal Journal of Educational Research, 9(3), 593 - 605. DOI: 10.13189/ujer.2021.090319.

Copyright $\mathrm{O} 2021$ by authors, all rights reserved. Authors agree that this article remains permanently open access under the terms of the Creative Commons Attribution License 4.0 International License

\begin{abstract}
The need to improve students' academic performance is paramount to distance learning educators. This study investigated the effect of face-to-face tutoring on academic performance of distance learners in the University of Cape Coast. Descriptive survey design with a quantitative approach was employed, using a sample of 1,491 out 44,134 students. A questionnaire developed by Gow and Kember was adapted and used for data collection. Both descriptive and inferential statistics were employed to analyse the data. The findings revealed that, all the eight elements used to measure students' perception on tutoring scored above the statistical mean threshold of 3.0. The findings further revealed that there were no statistically significant differences in the performance of students with negative or positive perceptions towards face-to-face tutoring. Though the predictive effect of tutoring on academic performance was positive, the findings further established that only three elements of tutoring (tutorial sessions, assessment and collaboration) positively affect respondents' academic performance, the rest do not. Implications for educational practice with reference to course-tutors were discussed. The study recommends that tutors should provide effective tutorial sessions that promote opportunity for collaboration. The study also
\end{abstract}

recommends to management to include course-tutors in students' assessment procedures.

Keywords Academic Performance, Distance Education, Elements, Face-to-Face Tutorials

\section{Introduction}

Research has shown that in distance education, broader forms of academic and social support seem to be important, regardless of whether the support is provided through face-to-face or online [1]. Tutoring support is an important aspect of students' learning experience as it allows for interactions and engagement from both teachers and students. Therefore, the expected outcome of tutoring is to make learners develop their own learning strategies based on student-centred learning approach so that academic supports and students strategies can lead to students' academic performance.

In higher education, particularly distance education institutions, tutoring has been a historical model for enhancing students' engagement as it forms an integral part 
of the teaching-learning process [2]. Face-to-face tutoring in distance education can be related to scaffolding, where tutors help students to expand their learning boundaries and learn more than when learning on their own. Thus helping students to achieve their professional goals [3]. Tutoring support is therefore the key in the overall assessment of educational service delivery [4,5] since it is used to supplement students' learning.

The tutor in distance education is normally likened to the teacher in the formal system of education but the role of the tutor in distance education is different compared to that of the conventional teacher. Tutors in distance education are expected to help learners develop self-determining and productive learning strategies [6] which should be translated into better academic performance, in terms of grades/class obtained. However, tutors of distance education are mostly recruited from the conventional education system with the assumption that as trained teachers, they can easily facilitate distance education programmes. A study by Akhter [7] revealed that most distance learning tutors/facilitators lacked the skills needed to help learners improve their learning. This is likely to affect tutors' ability to meet students' needs and ultimately have an effect on students' academic performance.

A variety of activities are involved in the tutoring process. A theoretical framework developed by Crisp and Cruz [8] had four elements of tutoring. These elements were specification of a role model, psychological and emotional support, academic knowledge support, and support for setting goals and choosing a career path. Gómez-Collado [9] believes that tutors should give advice, provide orientation and encourage students to develop good studying habits. Studies by William \& Kimberly [10] identified the intelligence of the tutor, nurturant, progressive, and encouragement as attributes of effective tutors and interpersonal factors that empower students and ensure personal connection [11]. It is assumed that tutors with these qualities are directly related to students' retention, early completion and reducing students' academic failure, which eventually leads to academic performance improvement.

Thus, the need to ensure that tutoring is modified to suit learners' interests and needs as opined by Guerra-Martín, Lima-Serrano and Lima-Rodríguez [12] becomes very relevant. Based on this assertion, the current study operationalised face-to-face tutoring with elements such as: critical thinking, self-directed learning, motivation, pedagogical content knowledge, counselling, assessment and face-to-face sessions.

Bailin [13] defines critical thinking as thinking of a particular quality, especially good thinking that meets specified criteria or standards of adequacy and accuracy. This concept is critical for distance learners due to their separation from the tutor. Self-directed learning teaches students how to learn and allows the individual to take the initiative and responsibility for what happens in the learning process [14]. Self-directed learning emphasizes goal setting, and choice making which are crucial to students' collaborative learning [15]. Motivation is a process accounting for an individual's direction, intensity and persistence of effort towards goals attainment [16]. A student's desire to enroll, participate and successfully complete an education programme is dependent on the gains to be made after the successful completion of the programme. Pedagogical content knowledge is a blend of competence used to teach or impact subject knowledge to learners [17].

Further, counselling is the talking therapy that is used to help students find ways to deal with academic and emotional issues [18]. The concept of assessment is important in every education enterprise. It provides students with feedback about themselves by assessing a number of factors including students' personality, learning styles, behaviour and performance [19]. Assessment acts as a motivator to students' performance, affects students' self-reflections as learners, and encourages them to be more honest and self-critical about their performance [19]. Lastly, Tutorial sessions are learner support systems in which the learner engages with the learning materials and the tutor [20].

\subsection{Statement of the Problem}

Though recent literature on distance education suggests a paradigm shift from the traditional learning support structures to technological media, the University of Cape Coast is yet to fully migrate its learners unto the e-learning platform. The tradition has been that students' study at the comfort of their homes with a print media supplied by the University and attends face-to-face tutorials fortnightly on weekends. Although attendance to face-to-face tutoring is not compulsory, it is used to supplement the reading materials given to students to study at home. Statistics from the University showed that for a period of six years most students graduated with a third or pass as shown in Figure 1 . 


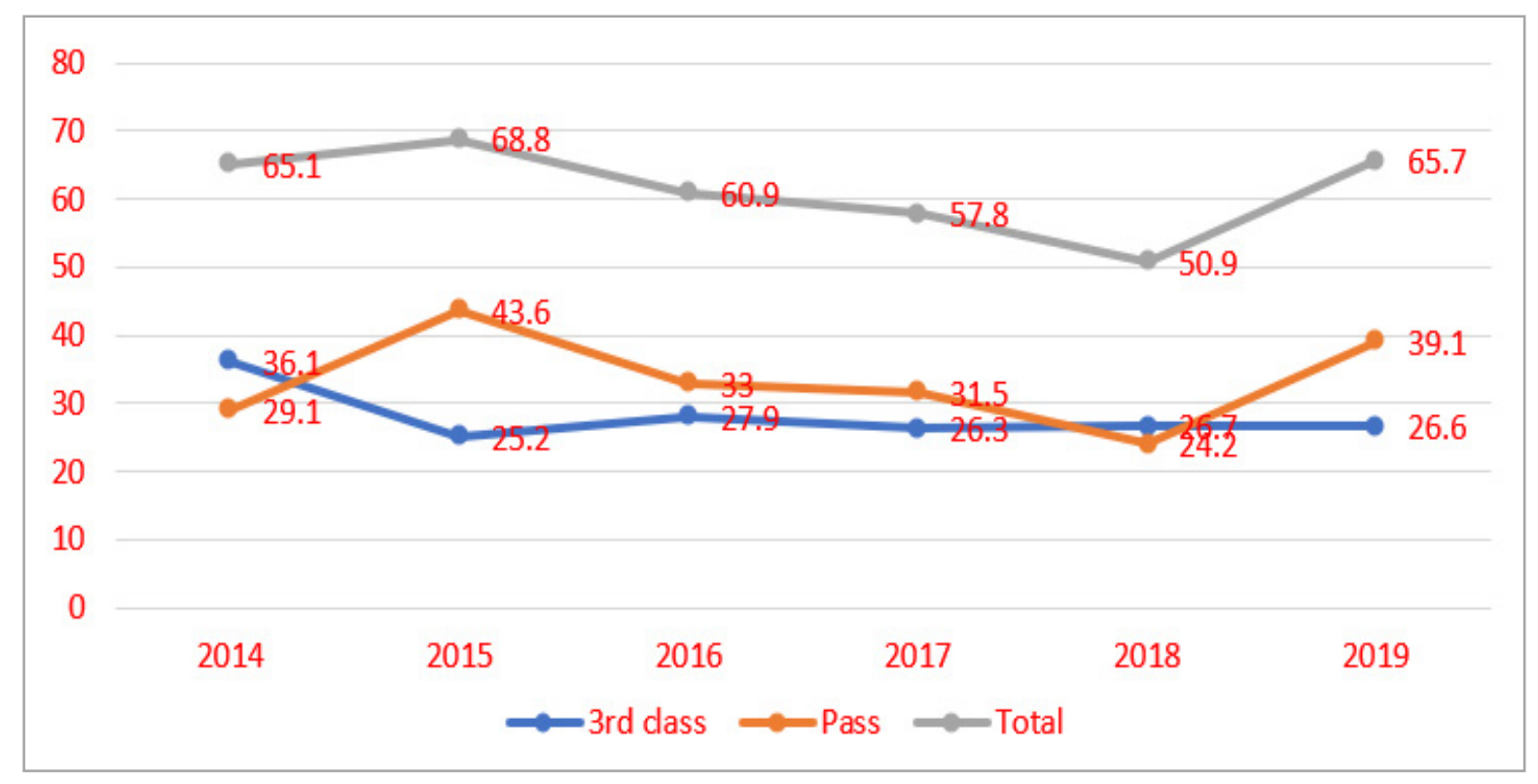

Figure 1. Summary of graduating statistics (in percentages) from 2014-2019

The incidence where the majority of the students fall within the third class and pass bracket has some implications for students and the University at large. For example, such students may miss the chance of furthering their education and getting employment, thereby compounding the current high unemployment rates in Ghana. With reference to the University, there is the high possibility of losing their prospective students to competitors.

Several studies have been conducted at the University to find solutions to the poor academic performance among students. Akuamoah-Boateng and Buadu's [21] study on tutors/students' perception of reducing attrition rate of distance learners at University of Cape Coast, indicated that pre-entry and monitoring counselling sessions could facilitate reduction in attrition among students. A major conclusion of the study was that, the college can attain a high level of persistence if the requisite support is given to learners to reduce their cognitive burden. With reference to the findings of the above study, Arhin, Wangeri and Kigen [22] assessed the impact of academic advising on students' retention at the College of Distance Education, University of Cape Coast, Ghana. The findings indicate that students' retention in distance learning is not predicted by academic advising. A major recommendation of the study was the provision of practical measures to address specific needs of students on the Distance Education programmes.

Subsequently, Dankyi [23] conducted a study to identify the counselling needs of distance students at the College of Distance Education. The findings of the study revealed that diploma students of the college had four broad priority counselling needs: Personal-social, Educational/academic Career/vocational and Practical needs. The study concludes that to enhance academic success, students' personal characteristics such as gender, age and level of study should be considered when identifying and meeting the counselling needs of students.

In another development, Somuah, Dankyi and Dankyi [24] looked at the study habits of learners on the Distance Education programme at the University of Cape Coast. The results of the study revealed that students hardly spent time revising their notes prior to face-to face interaction, failed to look for additional resources for their studies from the internet and were mostly unable to study for a minimum of three hours a day. The findings further revealed the need for guidance and counselling seminars on issues such as developing reading skills, prioritization of daily activities and time management. The study thus recommended the provision of guidance and counselling on effective study habits as a support service.

Despite all the recommendations, academic performance of students still remains low. The causes have either not been identified, dealt with or both. Further, none of these studies investigated whether face-to-face tutoring had any effect on the academic performance of the distance learner. It is evident that the perceptions of students were not sought on the effectiveness of tutoring support they received at the college. Since tutors are front line support providers, how students perceive their services is important. It therefore becomes imperative to find out how students on the distance-learning programme, perceive the tutoring support offered by the institution since it has a strong influence on their interaction and the depth of their learning.

\subsection{Purpose of the Study}

This study investigated the effect of face-to-face tutoring on students' academic performance using eight elements to 
conceptualise face-to-face tutoring. The study was guided by the following objectives:

1. Examine students' perceptions of the elements of face-to-face tutoring at the University of Cape Coast.

2. Assess the effect of face-to-face tutoring on students' academic performance at the University of Cape Coast.

3. Determine the differences in academic performance of students with positive or negative perceptions towards face-to-face tutoring at the University of Cape Coast.

\section{Conceptual Framework}

The study assumed that if students have positive perception towards the eight elements used to conceptualise face-to-face tutoring, then all other things being equal, students' academic performance should improve. On the other hand, a negative connotation of students on the elements of face-to face under consideration in the current study is likely to result in a decline in academic performance.

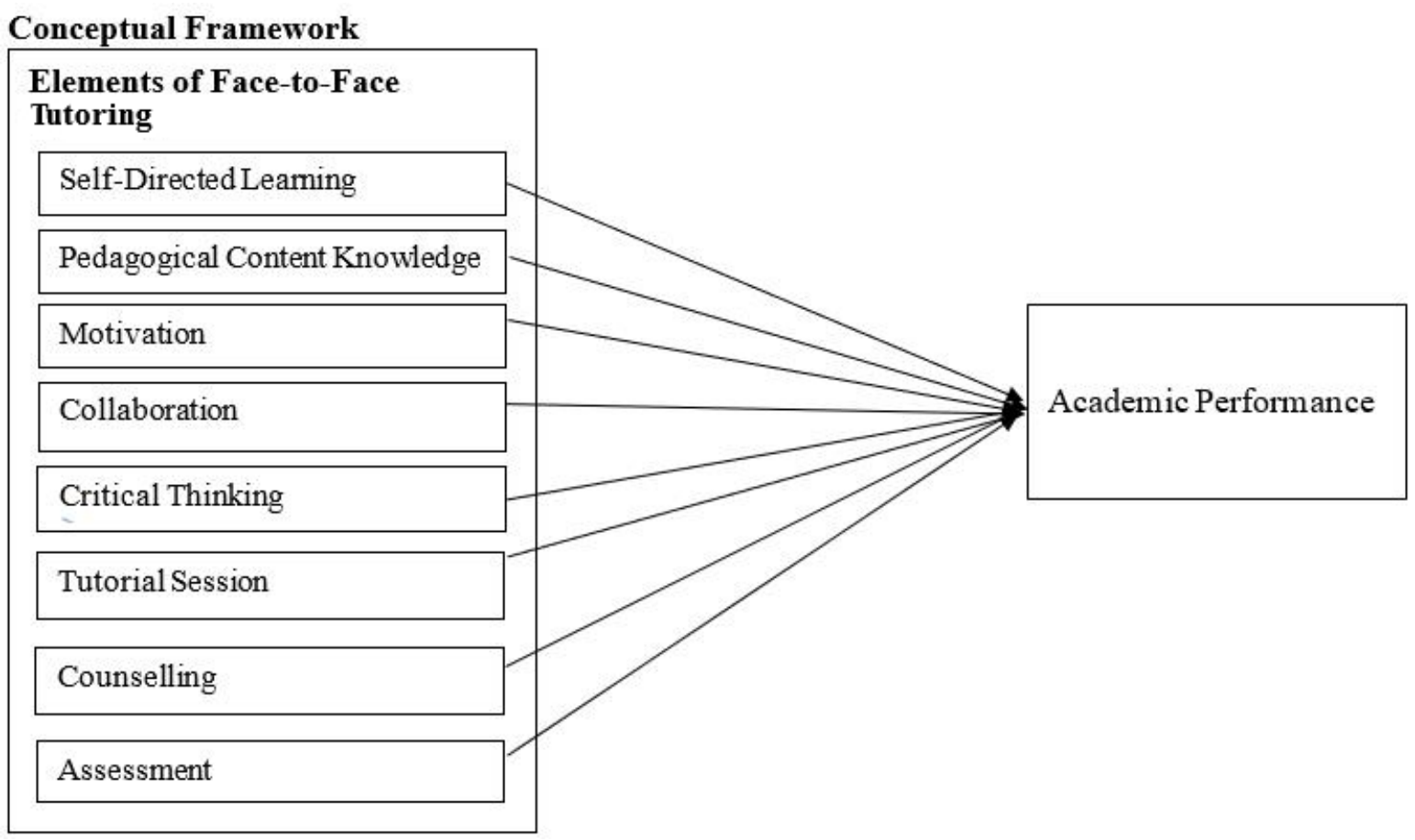

Figure 2. Conceptual framework of the effect of elements of face-to-face tutoring on academic performance 


\subsection{Literature Review}

Extant literature posits that scholars had over a period examined the contributions of some elements of face-to-face tutoring on students' academic performance and found out that certain elements of face-to-face tutoring have an effect on students' academic performance [25,26,27]. John and Michael [27] examined the extent to which self-directed learning practices relate to academic performance of undergraduate nursing students at the Nursing College of Mangalore. The analysis revealed that students with self-directed learning skills had high academic performance. Khiat [28] investigated how adults' perception of competence in self-directed learning relates to academic using 11 indicators. The findings revealed that the adult students' perceived level of competence in the 11 self-directed learning indicators had direct or indirect effect on their academic performance. Francis and Flanigan [29] conducted a study on self-directed learning and higher education practices using college students who completed the Oddi Continuing Learning Inventory (OCLI). The results revealed that self-directed learning is not directly related to academic performance.

Other studies also linked pedagogical competence to students' academic performance. A study by [30] to assess the influence of teacher pedagogical competence on students' academic performance revealed a positive relationship between the teaching methods used by teachers and academic performance of pupils. Another study was conducted by [31] to investigate teachers' pedagogical competence as determinants of students' attitude towards basic science in Southwestern Nigeria. The findings revealed that teachers' pedagogical competencies significantly influence students' attitudes towards Basic Science. Costa, Cardoso, Lima, Ferreira and Abrante [32] study on teacher pedagogical interaction and learning performance as determinants of academic achievement showed that perceived teacher pedagogical interactions with students positively and significantly influence students learning performance

Fitriwati [26] investigated the effect of students' intrinsic motivation and extrinsic motivation in English achievement of students at Bantan. The findings revealed a significant relationship between intrinsic and extrinsic motivation of students with English learning achievement. Neroni, Meijs, Gijselaers, Kirschner and Groot [33] conducted a study in the Netherlands to investigate how motivational factors such as management of time and effort, and contact with others affect students' academic performance. The results indicated that the management of time and effort positively affect students' academic performance, whereas contact with others had a negative effect on academic performance.

Further, Mora-Ruano, Heine and Gebhardt [34] investigated the extent to which teacher collaboration influenced students' achievement. The results indicated a positive effect of teacher collaboration on student achievement. In support of this, [35] conducted a study at Colorado School of Mines to examine the collaboration networks of students on academic performance through the use of nodal centrality measures. The results showed that students who collaborated often with many different colleagues tend to achieve higher academic performance.

Critical thinking and academic performance were also investigated by [36] in a study to assess the relationship between critical thinking skills, learning styles and academic achievement of nursing students studying at Islamic Azad University in Urmia, Iran. The findings revealed that there was no significant relationship between critical thinking and academic achievement. D'Alessio, Avolio and Charles [37] investigated how academic performance is influenced by critical thinking among master's students. Watson Glaser's critical thinking appraisal (WGCTA) was used by authors to measure the critical thinking, whiles average grade obtained by master's students was used to measure academic performance. The findings revealed a positive impact of critical thinking in all the studied academic areas.

Furthermore, Kay, Muola and Ondima [38] examined the extent to which guidance and counselling services influence students' academic engagement at Nyamira County in Kenya. The findings of the study revealed that all the respondents perceived school guidance and counselling services as effective in enhancing students' academic engagement. Eremie and Jackson [39] examined the influence of guidance and counselling services on the academic performance of secondary school students in Rivers State, Nigeria. The result indicated that counselling services significantly influence the academic performance of secondary school students in Rivers State. Ochola [40] investigated the relationship between guidance and counselling programme and students' academic achievement in the Kisumu east district of Kenya. From the study results, it was found that guidance and counselling had a strong and positive significant correlation with students' academic achievements.

Wang and Zhang [41] conducted a study to determine the effect of learning engagement and assessment on college students' academic performance. It was found that there was a positive influence between perceived teacher feedback and academic performance of students. A related study conducted by [42] among 7th and 8th grade pupils in public schools found that developmental assessment was constructive, motivating, allowing for self-evaluation and provides information for improving students learning outcome.

Miqdadi and Harris's [6] investigated the perception of first year engineering students on tutorials they received from the York University. The findings revealed that participants had a very high positive perception on tutorials with few of the participants feeling that tutorials were not beneficial to their academic performance. A related study 
[43] examined whether tutoring increase students' academic performance in Turkey. The conclusion drawn by the study was that academic performance among students was positively and significantly affected by tutoring.

The findings from the reviewed literature showed that all the eight elements used to conceptualize face-to-face affect academic performance directly or indirectly. Based on the review, the current study looks at the effect of the elements of face-to-face tutoring on the academic performance of distance education students in a Ghanaian context as a gap to be filled in literature. Since the majority of the studies were conducted outside the Ghanaian context.

\section{Methodology and Methods}

The study employed a descriptive survey design from the quantitative approach. The design permits the accurate description, observation, and documentation aspects of a situation as it occurs naturally [44]. Using a quantitative approach, the researchers employed quantitative methods to assess the magnitude and frequency of constructs to explore meaning and understanding of constructs [45]. The researchers also employed the descriptive and quantitative method because there was the need to obtain data from a large respondent on their perception regarding face-to-face tutoring through self-reported quantitative data.

The population of the study consisted of all students (diploma and post diploma) currently studying on the University of Cape Coast distance education programmes. In total, 44,134 (29,570 Education and 14,564 Business) students [46] formed the total population. Krejcie and Morgan [47] sample size determination table was used to sample 1,491 respondents (representing 3.37 percent) of the total population of 44,134 for the study. This sample size was based on a 2.5 per cent margin of error and a confidence interval of 95 per cent. This margin of error was chosen in order to obtain a large sample size from the population. Using the multistage sampling procedure, first, all the ten administrative regions of CoDE were purposively sampled for the study. Then after, the proportionate to size sampling technique [48] was used to calculate the percentage of students per region. Participants from each group were then selected through the stratified sampling technique. To ensure equal opportunity for selection of participants from each stratum (999 for Education and 492 for Business), the simple random sampling method was adopted. Only students who had a Cumulative Grade Point Average (CGPA) for two or more semesters were sampled for the study. Respondents of the study were to have at least a full year's academic experience with the university to be able to provide valid responses to the study items.

The data collection instrument was the questionnaire. Students' CGPA obtained from the Students' Records and
Management Unit of the CoDE was also used as a criterion to determine the academic performance of the students. The questionnaire employed for the study was adapted from Gow and Kember [49] students' perceptions of a good tutor. The 46-item questionnaire by [49] was used measure two major perspectives in higher education such as learning facilitation and knowledge transmission on a 5-point Likert-type scale with 1 representing low agreement and 5 representing high agreement. Gow and Kember [49] questionnaire adapted was conceptualized under eight elements: critical thinking, self-directed learning, motivation, pedagogical content knowledge, collaboration, counselling, assessment and tutorial sessions. Four items were however removed from the 46 items because they relate to audio-visual aids. Also, students do not receive audio-visual support materials from the facilitators at the University. Further, three items were also removed under pastoral care and the other items under pastoral care were placed under counselling to fit the context of the study. The remaining 39 items were modified and used for the current study.

The content validity of the instrument was achieved through the use of experts' knowledge in field of distance education. A pilot test of the instrument was conducted using 149 copies of the questionnaire (constituting $10 \%$ of the total sample for the study) from a study centre that was not included in the main data collection. Connelly [50] sample size determination procedure which states that $10 \%$ of a study sample is ideal for a pilot study served as the basis for the pilot. The internal consistency obtained through Cronbach's alpha coefficient of items measuring six of the face-to-face elements were above .70. However, the coefficients of items measuring collaboration (.65) and academic performance (.64) were below the threshold of .70. They were thus included in the study to satisfy for content validity as recommended by [51]. The overall Cronbach's alpha reliability for the 39 items was .94 . This falls in the acceptable region of .70, which is reliable [52]. Therefore, the instrument was used for data collection. A detail of the number of respondents, items measuring each variable and reliability statistics can be seen in Appendix "A".

Data was analysed using means, an independent t-test, and standard multiple regression analysis. The Likert-type scale measuring students' perception of face-to-face tutoring was categorized as negative and positive perceptions. A total mean score $(\mathrm{M} \leq 3)$ for a respondent was classified as having negative perception and a mean score $(M>3.1)$ for a respondent was categorized as having a positive perception. The threshold of the study was 3.0. To determine if a significant difference exists in the academic performance of students with positive or negative perceptions towards face-to-face tutoring, an independent sample t-test was conducted. To assess the effect of face-to-face tutoring on students' academic performance, a collinearity test was performed before the 
regression analysis to ensure there was no collinearity among the independent variables of the study. The test calculations were performed using SPSS version 21. The level of significance was set at $p$-value $=p \leq 0.05$.

\subsection{Logistical and Ethical Consideration}

Nine study centre coordinators were trained as research assistants to help in the distribution and collection of the copies of the questionnaire. Ethical considerations were adhered to by the researchers through safeguarding the privacy of respondents at all stages. Required Institutional Review Board (IRB) protocols were strictly adhered to. Formal informed consent letters outlining the intent and purpose of the study were issued to all the respondents. Respondents were assured of confidentiality of the information they provided and their identity was concealed. They were informed to participate in the study willingly. Pseudonyms were used to conceal the identity of the study centres sampled for the study. All cited sources in this work were referenced as a form of acknowledgement. In addition, all other necessary ethical considerations relating to public relation and human rights were adhered to as well as respecting and seeking consent from all appropriate authorities and chains of command during the field data collection [53].

\section{Results}

In all, 1,046 out of 1,491 questionnaires (representing $70 \%$ ) was validly completed and used for the analysis. The first research objective sought to examine students' perceptions towards face-to-face tutoring offered to distance learners at the University of Cape Coast. Students' perception of the face-to-face tutoring was measured by how students perceived all the eight indicators conceptualised under face-to-face tutoring. The indicators were: self-directed learning, pedagogical content knowledge, motivation, collaboration, critical thinking, tutorial sessions, counselling and assessment. Scale for determining low or high perception among respondents was based on a statistical mean 3.0 threshold. The results are presented in Table 1.

Table 1. Students' Overall Perceptions of Face-to-Face Tutoring

\begin{tabular}{cccccc}
\hline Variables & $\mathrm{N}$ & Min. & Max. & Mean & $\begin{array}{c}\text { Std. } \\
\text { Dev. }\end{array}$ \\
\hline $\begin{array}{c}\text { Self-Directed } \\
\text { Learning }\end{array}$ & 1046 & 1.00 & 5.00 & 3.9262 & .87016 \\
$\begin{array}{c}\text { Pedagogical Content } \\
\text { Knowledge }\end{array}$ & 1046 & 1.00 & 5.00 & 3.7465 & .85985 \\
Motivation & 1046 & 1.00 & 5.00 & 3.6401 & .93447 \\
Collaboration & 1046 & 1.00 & 5.00 & 3.6337 & .82196 \\
Critical Thinking & 1046 & 1.00 & 5.00 & 3.6266 & .85915 \\
Tutorial Sessions & 1046 & 1.00 & 5.00 & 3.5128 & .84505 \\
Counselling & 1046 & 1.00 & 5.00 & 3.3972 & .90884 \\
Assessment & 1046 & 1.00 & 5.00 & 3.2994 & 1.07749 \\
\hline
\end{tabular}

Source: Field data (2020).

Key: minimum $=$ Min., Maximum $=$ Max., Std. Dev. $=$ Standard Deviation

The findings in Table 1 revealed that all the eight elements measuring students' perception on face- to-face tutoring scored above the study's threshold of 3.0 with six obtaining very high scores. Self-directed learning obtained the highest score $(\mathrm{M}=3.9262 ; \mathrm{SD}=.87016)$ and Assessment $(\mathrm{M}=3.3972, \mathrm{SD}=.90884)$ yielded the lowest scores.

The second research objective sought to assess the effect of elements of face-to-face tutoring on students' academic performance. The results from the linear and multiple regression analysis are shown in Table 2.

Table 2. Effect of Elements of Face-to-Face Tutoring on Students' Academic Performance

\begin{tabular}{|c|c|c|c|c|c|c|c|c|c|c|c|c|}
\hline & \multirow{2}{*}{ Model } & \multirow{2}{*}{$\begin{array}{c}\text { Standardized } \\
\text { Coefficients } \\
\text { Beta }\end{array}$} & \multirow{2}{*}{$\mathrm{T}$} & \multirow{2}{*}{ Sig. } & \multicolumn{2}{|c|}{$\begin{array}{l}\text { 95.0\% Confidence } \\
\text { Interval for B }\end{array}$} & \multicolumn{2}{|c|}{$\begin{array}{l}\text { Collinearity } \\
\text { Statistics }\end{array}$} & \multirow{2}{*}{$\mathbf{R}^{2}$} & \multirow{2}{*}{$\begin{array}{l}\text { Adjusted } \\
\qquad \mathbf{R}^{2}\end{array}$} & \multirow{2}{*}{ df } & \multirow{2}{*}{$\begin{array}{c}\text { Effect } \\
\text { size }\end{array}$} \\
\hline & & & & & $\begin{array}{l}\text { Lower } \\
\text { Bound }\end{array}$ & $\begin{array}{l}\text { Upper } \\
\text { Bound }\end{array}$ & $\begin{array}{c}\text { Toleranc } \\
\mathrm{e}\end{array}$ & VIF & & & & \\
\hline \multirow{9}{*}{1} & (Constant) & & 21.399 & .000 & .213 & .256 & & & \multirow{9}{*}{.236} & \multirow{9}{*}{.230} & \multirow{9}{*}{$7(10)$} & \multirow{9}{*}{0.31} \\
\hline & Critical Thinking & .067 & 1.832 & .067 & -.004 & .102 & .562 & 1.780 & & & & \\
\hline & $\begin{array}{l}\text { Self-directed } \\
\text { learning }\end{array}$ & .066 & 1.731 & .084 & -.006 & .100 & .518 & 1.929 & & & & \\
\hline & Motivation & -.052 & -1.383 & .167 & -.098 & .017 & .535 & 1.869 & & & & \\
\hline & PC knowledge & .017 & .415 & .678 & -.046 & .070 & .473 & 2.116 & & & & \\
\hline & Collaboration & .133 & 3.520 & .000 & .045 & .157 & .531 & 1.882 & & & & \\
\hline & Counselling & .001 & .034 & .972 & -.065 & .068 & .403 & 2.480 & & & & \\
\hline & Assessment & .152 & 4.000 & .000 & .054 & .159 & .523 & 1.911 & & & & \\
\hline & Tutorial Sessions & .236 & 6.936 & .000 & .135 & .242 & .658 & 1.519 & & & & \\
\hline
\end{tabular}

Source: Field data (2020).

Key: PC- Pedagogical Content 
Results from Table 2 show that the collinearity statistics as indicated by variance inflation factors (VIF) ranged between 1.519 to 2.480 which were all lower than the 3.3 threshold as recommended by [51] and [54]. This means that the responses from the sample were free from multicollinearity. The simple linear regression results show elements that significantly affect participants' academic performance in the order of importance as tutorial sessions $(\mathrm{B}=.236, \quad \mathrm{p}$-value $=0.000) ; \quad$ assessment $\quad(\mathrm{B}=.152$, $\mathrm{p}$-value $=.000)$ and collaboration $(\mathrm{B}=.133$, $\mathrm{p}$-value $=.000)$. One can observe that critical thinking $(\mathrm{B}=.067$, $\mathrm{p}$-value $=.067)$; self-directed learning $(\mathrm{B}=.066$, $\mathrm{p}$-value $=.084)$, pedagogical content knowledge $(\mathrm{B}=.017$, $\mathrm{p}$-value $=.678)$, counselling $(\mathrm{B}=.001$, $\mathrm{p}$-value $=.972)$ and motivation $(\mathrm{B}=$ -.052 , p-value $=.167)$ do not statistically affect academic performance of the respondents.

In addition, the proportional contribution of all the eight elements of face-to-face tutoring explaining the variance in students' academic performance (dependent variable) was 23 percent with adjusted $\mathrm{R}^{2}$ of approximately .230 . This means that, besides the eight elements conceptualised under face-to-face-tutoring, there could be other elements which were not considered under this study but may affect respondents' academic performance. Further, an effect size of 0.31 was an indication that the predictive effect of the elements of face-to-face tutoring on academic performance of the respondents was positive and high.

A null hypothesis was formulated from the third research objective and tested as follows: There are no statistically significant differences in academic performance of students with positive or negative perceptions towards face-to-face tutoring at the University.

An independent sample t-test was conducted and the analysis is as shown in Table 3 .
The finding in Table $3(\mathrm{Sig}=.317)$ as indicated by the $\mathrm{Sig}(2$ tailed) under t-test for equality of means revealed that there were no statistically significant differences in scores respectively, for students with negative perception $[(\mathrm{M}=1.7667, \mathrm{SD}=1.38174)$ and positive perception $(\mathrm{M}=$ 2.0297, $\mathrm{SD}=1.58000) ; \mathrm{t}=(771)=-1.016]$. The study therefore failed to reject the null hypothesis. However, the mean score shows that students who had positive perception towards face-to-face tutoring were higher than those with negative perception.

\section{Discussion}

The findings of research objective one revealed that six (self-directed learning, pedagogical content knowledge, motivation, collaboration, critical thinking, tutorial session) out of the eight elements measuring face-to-face tutoring were perceived to be very high by students. This is evident to the findings of $[27,28,31,30,26,33,34,35,36,43,2,6]$ whose studies found that students have positive perception towards self-directed learning, pedagogical content knowledge, motivation, collaboration, critical thinking and tutorial sessions. The findings on counselling contradicts that of $[38,39,40]$. That of assessment, also contradicts the findings of $[42,41]$

Further, respondents' high score for self-directed learning shows that students are aware that they need to study on their own with minimal support from the tutor. As emerged from the study, tutors' pedagogical content knowledge was also rated very high by respondents. This is not surprising because tutors are scrutinized by the University to make sure they possessed the pedagogical competencies and are only allowed to teach in their areas of specialization.

Table 3. T-test Results Showing the Difference in Academic Performance of Students with Positive or Negative Perceptions towards Face-to-Face Tutoring

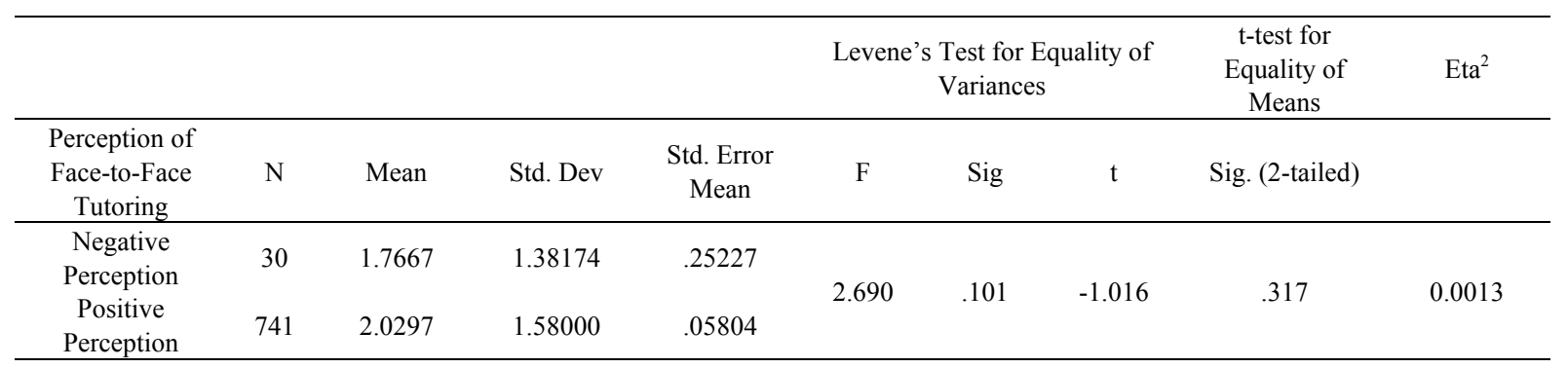

Source: Field data (2020). 
Besides, respondents' positive perception towards motivation may be due to the fact that the majority of distance learners are adults who have enrolled for upgrading and self-improvement and therefore are motivated intrinsically to achieve their goals. Collaboration among learners is also crucial to their academic success based on the assumption that knowledge acquisition is an interplay between collaborators in the learning process. This is very true among distance students who are usually separated by physical distance and find themselves studying alone most of the time. Such collaborations support them to improve their ability to share knowledge and information that is crucial to their academic work. The respondents' positive perception of tutorial sessions shows that tutorials play a key role in students' academic pursuits. The finding may mean that students perceived tutorials as very important because it affords them the opportunity to seek clarification of concepts and ideas which appeared difficult as they study their materials on their own.

The score for counselling was also above the study's mean threshold of 3.0, which shows that participants believed counselling services improve academic performance likewise that of assessment and feedback. This is important because students are able to readily identify their weaknesses and put in the needed measures to rectify them. The overall findings for research objective one show that the participants had a positive perception towards all the elements of face-to-face tutoring used in the study.

The findings of research objective two revealed that elements such as tutorial sessions, assessment and collaboration significantly affected academic performance of distance students. The picture portrayed by the findings is in agreement with other studies. For instance, on the issue of assessment, [42,41] found that the number of assessments in a given semester positively affect students' academic achievement. Berberoğlu and Tansel [43] and [6] found that while tutorial sessions had a positive and significant effect on students' academic performance. It also afforded instructors the opportunity to boost students' engagement. This finding is congruent with the results of [34] who found that collaboration between students, tutors and administrators significantly affect students' performance.

The result for research objective three revealed that there were no statistically significant differences in scores of participants with negative or positive perception towards face-to-face tutorials. This could mean that the type of perception, respondents' holds about face-to-face tutoring did not have any link with their academic performance. The finding is in contrast with studies of [6] who found that participants had differences in the perception they held about tutorials sessions. The implication is that a participant's positive or negative perception towards face-to-face tutoring, does not seem to have any influence on their academic work.

However, the other elements such as critical thinking, self-directed learning, pedagogical content knowledge, counselling and motivation do not affect respondents' academic performance. This could mean that although respondents have positive perception of these elements of face-to-face tutoring, the way and manner they are provided by the tutors do not make them relevant in their academics.

\section{Conclusions}

The results showed that, respondents had positive perception towards the elements used to conceptualised face-to-face tutorials offered at the College. The findings also revealed that there were no statistically significant differences in academic performance of students with negative or positive perception towards face-to-face tutoring. Further, the findings revealed that, three of the elements of face-to-face tutoring; tutorial sessions, assessment and collaboration significantly affected students' academic performance. Implication for educational practice was discussed to assist tutors to provide instructional strategies that support effective tutorial sessions, provide periodic assessment and enhance collaboration.

\subsection{Implications for Educational Practice}

The present findings of the study have implications for course tutors and students. There are numerous benefits of tutoring in distance education. Course tutors need to provide effective tutorial sessions to help students develop study and learning skills that improve academic performance. With effective tutorial sessions, students can take initiative of their work, build their self-esteem and increase their confidence level. Students must be educated and encouraged to attend all tutorial sessions provided by the college as part of student support service.

On the issue of collaboration, course-tutors need to acquire the skills about how to promote effective collaboration among students and tutors. Collaboration enhances students' motivation and interest. Thus, students must be encouraged to form study groups, develop communication and interpersonal skills that would help make learning experiences more meaningful to them. Again, tutors interaction with students during tutorial sessions could help to clarify concepts to students and enable them to develop a more personal relationship with tutors and among themselves.

Further, course tutors need to be empowered by the college to provide frequent assessment and feedback to students. When feedback is given, it helps to modify 
students' academic goals. In addition, assessment also enables students to assess the effectiveness of their own learning and also determine whether they are meeting the objectives of the course. It is therefore necessary to enhance structures for effective assessment in order to help meet students' academic goals.

Lastly, although tutors' pedagogical content knowledge did not affect respondents' academic performance, [54] assert that teachers are expected to process and evaluate new knowledge relevant for core professional practice. Tutors in distance learning need to evaluate their pedagogical content knowledge to enable them meet the demands of the learners during face-to-face tutoring. This could be done by providing periodic in-service training for course tutors by the college.

\subsection{Limitations of the Study}

First, the study was purely quantitative as such students' self-expression responses were not solicited which could have given a further insight into the findings. For instance reasons why elements such as critical thinking, self-directed learning, pedagogical content knowledge, counselling and motivation do not affect students' academic performance. Second, the study limited itself to only eight elements of face-to-face tutoring that could affect academic performance relegating other factors (such as emotional support, support for setting goals and student empowerment) in literature. Also, only academic performance was used as a dependent variable although there were other dependent variables (such as satisfaction, retention and programme continuance intentions) which could have been investigated.

\subsection{Recommendations}

The study recommends that, management of the College of Distance Education of the University should organise in-service training for course tutors to build their pedagogical content knowledge. It is also recommended the college put in place structures to include course tutors in the assessment procedures of students since frequent assessments have the potential to improve students' academic performance.

\subsection{Suggestions for Further Studies}

1. Further studies could look at the effect of the elements of face-to-face tutoring on students' academic performance using a mixed method approach for in depth understanding.

2. Additionally, another study could look at the effect of the elements of face-to-face tutoring on students' retention.

3. Lastly, a study involving tutors as study participants should be conducted to find their views on face-to-face tutoring.

\section{Acknowledgement}

We are most grateful to the Directorate of Research, Innovation and Consultancy (DRIC) of the University of Cape Coast for funding this project.

\section{Appendix A: Reliability Statistics for Data Collection Instrument}

\begin{tabular}{|c|c|c|c|c|c|c|}
\hline \multirow[b]{2}{*}{$\mathbf{s} / \mathbf{n}$} & \multirow[b]{2}{*}{ Variable } & \multirow[t]{2}{*}{$\mathbf{N}$} & \multirow[b]{2}{*}{ No. of items } & \multirow{2}{*}{$\begin{array}{l}\text { Cronbach's } \\
\text { Alpha }\end{array}$} & \multirow{2}{*}{$\begin{array}{c}\text { KMO and Bartlett's Test } \\
\text { KMO }\end{array}$} & \multirow[b]{2}{*}{ Sig } \\
\hline & & & & & & \\
\hline 1 & Critical thinking & 149 & 4 & .757 & .654 & .000 \\
\hline 2 & Self-Directed Learning & 149 & 3 & .784 & .685 & .000 \\
\hline 3 & Motivation & & 3 & .724 & .614 & .000 \\
\hline 4 & $\begin{array}{l}\text { Pedagogical Content } \\
\text { Knowledge }\end{array}$ & 149 & 4 & .819 & .643 & .000 \\
\hline 5 & Collaboration & 149 & 3 & .647 & .667 & .000 \\
\hline 6 & Counselling & & 7 & .878 & .843 & .000 \\
\hline 7 & Assessment & 149 & 4 & .801 & .628 & .000 \\
\hline 8 & Tutorial Sessions & 149 & 5 & .820 & .707 & .000 \\
\hline 9 & Academic performance & 149 & 6 & .635 & .541 & .000 \\
\hline 10 & All Variables & 149 & 39 & .939 & & \\
\hline
\end{tabular}




\section{REFERENCES}

[1] Jelfs, A., Richardson, J. T. E., \& Price, L., "Student and tutor perceptions of effective tutoring in distance education", Distance Education, vol.30, no. 3, pp. 419-441, 2009. DOI: $10.1080 / 01587910903236551$

[2] Faroa, B. D., "Considering the role of tutoring in student engagement: Reflection from a South African University", Journal of Student Affairs in Africa, vol. 5, no. 2, pp. 1-15, 2017.DOI: 10.24085 /jsaa.v5i2.2699 1

[3] Morillas, N. R. \& Garrido, M. F., "The role of tutoring in higher education: improving the student's academic success and professional goals", Revista Internacional de Organizaciones, vol. 12, pp. 89-100, 2014. https://dialnet.unirioja.es/descarga/articulo/4994821.pdf

[4] Olivier, B. H., "The impact of contact sessions and discussion forums on the academic performance of open distance learning students", International Review of Research in Open and Distributed Learning, vol. 17, no. 6, pp. 75-88, 2016. DOI:10.19173/IRRODL.V17I6.2493

[5] Lowe, T., Mestel, B., \& Williams, G., "Perceptions of online tutorials for distance learning in mathematics and computing", Research in Learning Technology, vol. 24, no. 1, pp. 1-14, 2016. doi: 10.3402/rlt.v24.30630

[6] Miqdadi, M., \& Harris, J., 'Investigating students' perceptions of first-year engineering tutorials". Canadian Engineering Education Association Conference, University of Ottawa, June 9-12, 2019, Paper 103

[7] Akhter, N., "Effectiveness of tutors' role in distance education", Journal of Educational Research, vol. 15, no. 2, pp. 50-57, 2012. https://www.questia.com/library/journal/1 P3-3147294531/effectiveness-of-tutors-role-in-distance-edu cation

[8] Crisp, G., \& Cruz, I., "Mentoring college students: A critical review of the literature between 1990 and 2007", Research in Higher Education, vol. 50, pp. 525-545, 2009. doi:10.1007/s11162-009-9130-2

[9] Gómez-Collado, M. E., "The perception of students on the academic tute-lage", Convergencia. Revista de Ciencias Sociales, vol. 58, pp. 209-233, 2012. https://www.redalyc.o rg/pdf/105/10520680002.pdf

[10] William, B. W. \& Kimberly, D. T., "The role of the lecturer as tutor: Doing what effective tutors do in a large lecture class". Life Sciences Education, vol. 11, pp. 3-9, 2012. doi: $10.1187 /$ cbe.11-12-0110

[11] Guerra-Martín, M. D., "Tutoring as a way of achieving employability for nursing students at the University of Seville", Procedia-Social and Behavioral Sciences, vol. 139, pp. 479-486, 2014. doi:10.1016/j.sbspro.2014.08.049

[12] Guerra-Martín, D., Lima-Serrano, M. \& Lima-Rodríguez, J. S.,"Effectiveness of tutoring to improve academic performance in nursing students at the University of Seville", Journal of New Approaches in Education Research, vol. 6, no. 2 , pp. 93 - 103, 2017. DOIhttps://doi.org/10.7821/naer. 2017.7.201
[13] Lai, R. E. “Critical thinking: A literature review”. Research Report: New York, Pearsons Inc., 2011. http://www.pearso nassessments.com/.

[14] Timpau, C., "Importance of self-directed learning". Logos Universality Mentality Education Novelty, Social Sciences, vol. 4, no. 1, pp. 37-49, 2015. http://lumenjournals.com/soci al-sciences/

[15] Gilbert, N., \& Driscoll, M., "Collaborative knowledge building: A case study", Educational Technology Research and Development, vol. 50, pp. 59-79, 2002. DOI: 10.1007/BF02504961

[16] Robbins, S. P. \& Judge, T. A., "Organizational behaviour", $15^{\text {th }}$ Edition, Boston, M. A., Education Pearson, 2013

[17] Nind, M., "A new application for the concept of pedagogical content knowledge: Teaching advanced social science research methods", Oxford Review of Education, vol. 46, no. 2, pp. 185-201, 2019. DOI: 10.1080/03054985.2019.16449 96

[18] National Counselling Society, Types of Therapy., Retrieved from:

https://www.nationalcounsellingsociety.org/find-counsellor /types-of-therapy/

[19] Taylor, A. I., \& Buku, D. K., "Basics in guidance and counselling" ( $2^{\text {nd }}$ ed.). Ghana, Accra: Yamens Press Ltd., 2006.

[20] Ogina, T. A., \& Mampane, S., "Experiences of tutorial sessions as learning support for distance students", Conference paper, 2010. Retrieved from: https://www.resea rchgate.net/Publication/271849330

[21] Akuamoah-Boateng, C., \& Boadu, K. "Reducing distance learners' attrition rate at the University of Cape Coast: Tutors'/students' perception", International Journal of Learning \& Development, vol. 3, no. 3, pp. 214-229, 2013.

[22] Arhin, V., Wangeri, T., \& Kigen, E., "Academic advising and student retention in distance learning: The case of University of Cape Coast, Ghana”. Journal of Educational and Social Research, vol. 7, no. 3, pp. 25-38, 2017. DOI: 10.30918/AERJ.63.18.043

[23] Dankyi, A. L., "Identifying and meeting the counselling needs of distance learners as shapers of students' academic success: The case of University of Cape Coast, Ghana". Open Journal of Social Sciences, vol. 7, no. 12, pp. 12-25, 2019. DOI: $10.4236 /$ jss.2019.712002

[24] Somuah, B. A., Dankyi, A. L., \& Dankyi, K. J., “An investigation into the study habits of distance learners: Implications for guidance and counseling services". Mediterranean Journal of Social Sciences, vol. 5, no. 6, pp. 273-282, 2014. DOI: 10.5901/mjss.2014.v5n6p273

[25] Abdurrahman, S. M., \& Garba, M. I., "The impact of motivation on students' academic achievement in Kebbi state junior secondary school Mathematics", International Journal of Advance Research, vol. 2, no. 12, pp. 1 - 15, 2014.

[26] Fitriwati, D. G., "The effect of motivation on the learning achievement". IJIELT, vol. 4, no. 1, pp. 198-207, 2018. http://ejournal.uinsuska.ac.id/index.php/IJIELT/article/view $/ 6666$ 
[27] John, J. V., \& Michael, J. C., "Self-directed learning practices and academic performance among undergraduate nursing students". International Journal for Research in Applied Science \& Engineering Technology, vol. 6, no. 3, pp. 1173-1177, 2018. doi.org/10.22214/ijraset.2018.3183

[28] Khiat, H., "Academic performance and the practice of self-directed learning: The adult student perspective". Journal of Further and Higher Education, vol. 4, no. 1, pp. 44-59, 2017. DOI:10.1080/0309877X.2015.1062849

[29] Francis, A., \& Flanigan, A., "Self-directed learning and higher education practices: Implications for student performance and engagement", Mountain Rise, vol. 7, no. 3, pp. 1- 18, 2012.

[30] Teygong, L., Kapkiai, M., \& Oduor, D., "Influence of teacher pedagogical competencies on pupils' academic performance in public primary schools in Kenya", European Journal of Education Studies, vol. 3, no. 12, pp. 565-583, 2017. DOI: $10.5281 /$ zenodo. 1156387

[31] Adegbola, F. F., “Teachers' pedagogical competence as determinants of students' attitude towards basic science in Southwest Nigeria", Educational Research and Reviews, vol. 14, no. 18, pp. 655-660, 2019.

[32] Costa, C., Cardoso, A. P., Lima, M. P., Ferreira, M., \& Abrantes, J. L., "Pedagogigal interaction and learning performance as determinants of academic achievement". Procedia-Social and Behavioral Sciences, vol. 29, pp. 1596-1605, 2015. DOI:10.1016/j.sbspro.2015.01.203

[33] Neroni, J., Meijs, C., Gijselaers, H. J. M., Kirschner, P., \& de Groot, R. H. M. "Learning strategies and academic performance of distance education". Learning and Individual Differences vol. 17, pp. 1-7, 2019. https://doi.org/10.1016/j.lindif.2019.04.007

[34] Mora-Ruano, J. G., Heine, J. H., \& Gebhardt, M., "Does teacher collaboration improve student achievement? Analysis of the German PISA 2012 Sample". Front Educ, vol. 4, no. 85, 2019. DOI:10.3389/feduc. 2019.00085

[35] Vargas, D. L., Bridgeman, A. M., Schmidt, D. R., Kohl, P.B., Wilcox, B. R., \& Carr, L. D., "Correlation between student collaboration network centrality and academic performance. Physical Review, vol. 14, no. 020112, pp. 1-11., 2018. DOI:https://doi.org/10.1103/PhysRevPhysEducRes.14.0201 12

[36] Shirazi, F., \& Heidari, S., "The relationship between critical thinking skills and learning styles and academic achievement of nursing students", Journal of Nursing Research, vol. 27, no. 4, pp. 38-48, 2019. doi: 10.1097/jnr.0000000000000307

[37] D’Alessio, F. A., Avolio, B. E, \& Charles, V., "Studying the impact of critical thinking on academic performance of executive MBA students". Thinking Skills and Creativity, vol. 31, pp. 275-283, 2019. https://doi.org.10.1016/j.tsc.201 9.02 .002

[38] Kay, J., Muola, J., \& Ondima, P. C., "Influence of guidance and counselling programmes on secondary school students' academic engagement in Nyamira County, Kenya”, Journal of Education and Practice, vol. 10, no. 29, 101-113, 2019. DOI: $10.7176 / \mathrm{JEP} / 10-22-06$
[39] Eremie, M. D., \& Jackson, S., "Influence of guidance and counselling services on academic performance of secondary school students in Rivers state". International Journal of Innovative Human Ecology and Nature Studies, vol. 7, no. 1, 14-21, 2019. http://www.escijournals.net/IJES

[40] Ochola, M. O., "Relationship between guidance and counselling programme and students' academic achievement in secondary schools in Kisumi east district, Kenya", Unpublished Master of Education Thesis, Maseno University, 2015. https://repository.maseno.ac.ke/bitstream /handle/123456789/784/Relationship

[41] Wang, S., \& Zhang, D., "Perceived teacher feedback and academic performance: the mediating effect of learning engagement and moderating effect of assessment characteristics", Assessment \& Evaluation in Higher Education, 2020. Doi: 10.1080/02602938.2020.1718599

[42] Tavdgiridze, L., Sherozia, N., Mamuladze, N., \& Khasaia, I., 'Formative assessment promoting students' academic performance", INTED2020 Proceedings, pp. 1687-1695, 2020. DOI: 10.21125 /inted.2020.0545

[43] Berberoğlu, G., \& Tansel, A. (2014). "Does private tutoring increase students' academic performance? Evidence from Turkey”. IZA Discussion Paper No. 8343. The Institute for the Study of Labor (IZA) in Bonn, Germany. DOI: 10.1007/s11159-014-9436-y

[44] Creswell, J. W., "Research design: Qualitative, quantitative and mixed methods approaches", (4th ed.). Thousand Oaks: Sage, 2014, pp. 200-213

[45] Creswell, J. W., \& Plano Clark, V. L., "Designing and conducting mixed methods research" (2nd ed.), London: Sage, 2011.

[46] UCCOSIS, University of Cape Coast, 2019

[47] Krejcie, R. V., \& Morgan, D. W., "Determining sample size for research activities: Educational and Psychological Measurement”. New York, NY: Sage, 1970. https://doi.org/ $10.1177 / 001316447003000308$

[48] Kothari, C. R., "Research methodology: Methods and techniques" (2nd ed.). New Delhi: New Age International, 2013

[49] Gow, L., \& Kember, D., "Conceptions of teaching and their relationship to student learning", British Journal of Educational Psychology, vol. 63, pp. 20-33,1993. https://doi.org/10.1111/j.2044-8279.1993.tb01039.x

[50] Connelly, L. M., "Pilot Studies". Medsurg Nursing, vol. 17, no. 6 , pp. 411-412, 2008. https://pubmed.ncbi.nlm.nih.gov/ $19248407 /$

[51] Hair, J. F., Hult, G. T. M., Ringle, C. M., \& Sarstedt, M., “A primer on partial least squares structural equation modelling" (2nd ed.). Thousand Oaks: Sage, 2017.

[52] Kline, R. B., "Principles and practice of structural equation modelling methodology in the social sciences (3rd ed.), Guilford Press: NY, 2015.

[53] Orodho, J. A., "Elements of education and social science research methods", ( $4^{\text {th }}$ ed.), Maseno: Kenezja Publisher, 2016. 
[54] Kock, N., \& Lynn, G., "Lateral collinearity and misleading results in variance-based SEM: An illustration and recommendations". Journal of the Association for Information Systems, vol. 13, no.7, pp. 1-40, 2012. DOI: $10.17705 / 1$ jais.00302
[55] Filgona, J., Sakiyo, J., \& Gwany, D. M., "Teachers' pedagogical content knowledge and students' academic achievement: A theoretical overview", Journal of Global Research in Education and Social Sciences, vol. 14, no. 2, pp. $14-44,2020$ 